\title{
Natural and built environments and quality of life in EU member states
}

\author{
Dalia Streimikiene \\ Mykolas Romeris University \\ Lithuania \\ e-mail:daliastreimikiene@mruni.eu
}

\begin{abstract}
The natural and built environment are very important for quality of life. The
Received:

June, 2014 housing indicators are suitable to address the main issue of built environment. The indicators for assessment of natural environment reflecting the quality of life can be assessed by applying the following groups of indicators: environmental quality, environmentally responsible behavior and consumption of environmental services. The paper presents the concept of evaluation of natural and built environment in overall quality of life assessment and presents trends of the main indicators relevant to these dimensions of quality of life in EU member states.

1st Revision: September, 2014

Accepted:

October, 2014

DOI:

$10.14254 / 2071-$ $8330.2014 / 7-3 / 1$
\end{abstract}

Keywords: quality of life, natural environment indicators, built environment indicators.

JEL classification: $\mathrm{I} 31, \mathrm{I} 38, \mathrm{O} 47$

\section{INTRODUCTION}

The main aim of sustainable development - to ensure a quality of life for current and future generation and the quality of life depends on economic, social and environmental dimensions of sustainability (Albouy, Godefroy, Lollivier, 2010), (Boarini et.al., 2010). Quality of life should not be mixed with the concept of standard of living, which is based primarily on income (Dolan, Peasgood, White, 2008). The quality of life is a broader concept and the standard indicators of the quality of life include not only wealth and employment but also the natural and built environment, physical and mental health, education, recreation and leisure time, social belonging, etc. (Helliwell, Barrington-Leigh, 2010).

There is a direct relationship between quality of life and environment (Diener, Eunkook, 1997). People's lives are strongly affected by the healthiness of their physical environment. The impact of pollutants, hazardous substances on people's health is considerable. Environmental quality also matters intrinsically, as most people value the beauty and healthiness of the place where they live, and care about the depletion of its natural resources (Brajša-Žganec, Merkaš, Šverkok, 2010). Preserving environmental and natural resources is also one of the most important challenges for ensuring the sustainability of well-being over time (Van Liere, Dunlap, 1980). Environmental policies have a critical role to play in dealing with global health priorities and in improving people's environmentally responsible behavior and also lives (Reto, Garcia-Vega, 2012).

Environmental quality is a key dimension of people's well-being, as quality of life is strongly affected by a healthy physical environment (Kahn, 2002), (Holman, Coan, 2008). 
The term natural environment encompasses all living and non-living things occurring naturally on Earth or some region thereof (Ahmad, Yamano, 2011). Besides affecting people's health, the natural environment also matters intrinsically as many people attach importance to the beauty and the healthiness of the place where they live, and because they care about the degradation of the planet and the depletion of natural resources (Balestra, Dottori, 2012), (Kahn, Matsusaka, 1997). People also directly benefit from natural environmental assets and services, such as water, clear air, lands, forests, and access to green spaces, as they allow them to satisfy basic needs and to enjoy free time and the company of others (Pretty et. al., 2005), (Balestra, Sultan, 2013).

The term built environment refers to the human-made surroundings that provide the setting for human activity, ranging in scale from buildings and parks or green space to neighborhoods and cities that can often include their supporting infrastructure, such as water supply, or energy networks. The built environment is a material, spatial and cultural product of human labor that combines physical elements and energy in forms for living, working and playing. It has been defined as "the human-made space in which people live, work, and recreate on a day-to-day basis (Mohit, 2013).

It is important to develop the set of indicators to measure built environment conditions in housing sector providing information about both the physical characteristics of the dwelling (e.g. availability of electricity, water supply, indoor flushing toilets, bathroom requirements etc.) and the broader environmental characteristics of the areas where the dwellings are located (e.g. exposure to noise, indoor pollution, etc.). The housing costs also very important as high housing costs can hamper households' material well-being and economic security.

The quality of natural and built environment is one of the most important challenges for ensuring the sustainability of well-being over time. However, measuring of environmental indicators is difficult; first, because the size of the impacts of current environmental trends and housing quality on future well-being is uncertain; second, because there are few comparable indicators that meet agreed standards.

The aim of this paper is to develop a framework for assessment of natural and built environmental indicators relevant to quality of life and to apply this framework for comparative assessment of environment indicators of quality of life in EU member states.

The main tasks to achieve this aim are as follows:

- To select indicators for assessment of natural and built environment relevant to quality of life based on EUROSTAT database;

- To analyse and compare the trends of environmental indicators in EU member states;

- To develop policy recommendations based on the analysis carried out by the authors.

\section{INDICATORS OF BUILT AND NATURAL ENVIRONMENT RELEVANT TO QUALITY OF LIFE}

Quality of life is a complex, multi-faceted construct that requires multiple approaches from different theoretical perspectives. The objective approach supposes to use objective indicators that reflect different aspects of quality of life measurable by using secondary data, available mainly from official governmental data collections. This approach is widely used in different studies as it has major advantages. Quality of life research in Lithuania is not well developed yet. Recently the interest on this topic has been growing (Rybakovas, 2011), (Rybakovas, 2012), (Rakauskiene, Servetkiene, 2011), (Tvaronaviciene, 2011). Most empirical studies in Lithuania paid most attention just to the objective component of quality of life. The quality 
of life according (Rakauskiene, Servetkiene, 2011) can be measured by indicators covering the following 3 main dimensions:

- Health, environment and demographics;

- The material conditions of life;

- Education, culture, moral, ethical and spiritual values.

The environmental indicators of quality of life are included in the first dimension of quality of life covering health, environment and demographic conditions.

As it was mentioned before there are natural and built environment indicators important for assessing quality of life. The term natural environment encompasses all living and non-living things occurring naturally around us on Earth or on some territory under investigation.

The most important natural environment indicators relevant to quality of life would inform about quality of a number of environmental media (soil, water, air), on people access to environmental services and amenities and environmentally responsible behavior as well (Mace, Bell, Loomis, 1999). Consumption of environmental services and amenities has also direct impact on quality of life. On the other hand the quality of environment and environmental services and amenities are affected by human behavior. The environmentally responsible behavior is the main driver of environmental quality of environmental services provided (Osbaldiston, Sheldon, 2003), (Thogersen, 2006). The objective natural environment indicators of quality of life presented in this paper are limited to only a subset of indicators reported by EUROSTAT databases.

Table 1

The quality of life and environment

\begin{tabular}{|c|c|c|c|c|}
\hline \multirow{3}{*}{$\begin{array}{l}\text { Built } \\
\text { environ- } \\
\text { ment }\end{array}$} & $\begin{array}{l}\text { Housing } \\
\text { quality }\end{array}$ & $\begin{array}{l}\text { Overcrowding rate, } \\
\%^{2}\end{array}$ & $\begin{array}{l}\text { Housing deprivation rate by } \\
\text { number of item, \% }\end{array}$ & $\begin{array}{l}\text { Share of population considering } \\
\text { their dwelling too dark, } \%\end{array}$ \\
\hline & $\begin{array}{l}\text { Housing } \\
\text { environ- } \\
\text { ment } \\
\end{array}$ & $\begin{array}{l}\text { Crime, violence or } \\
\text { vandalism in the } \\
\text { area, } \%\end{array}$ & $\begin{array}{l}\text { Noise from neighbours or } \\
\text { from the street, } \%\end{array}$ & $\begin{array}{l}\text { Pollution, grime or other environ- } \\
\text { mental problems, } \%\end{array}$ \\
\hline & $\begin{array}{l}\text { Housing } \\
\text { expen- } \\
\text { ditures } \\
\text { burden } \\
\end{array}$ & $\begin{array}{l}\text { The housing cost } \\
\text { overburden rate, } \%\end{array}$ & $\begin{array}{l}\text { Inability to keep home ad- } \\
\text { equately warm, \% }\end{array}$ & $\begin{array}{l}\text { The share of housing costs in dis- } \\
\text { posable household income, cost, \% }\end{array}$ \\
\hline \multirow{3}{*}{$\begin{array}{l}\text { Natural } \\
\text { environ- } \\
\text { ment }\end{array}$} & $\begin{array}{l}\text { Environ- } \\
\text { mental } \\
\text { quality }\end{array}$ & $\begin{array}{l}\text { Urban population ex- } \\
\text { posure to air pollution } \\
\text { by particulate matter, } \\
\text { micrograms per cubic } \\
\text { meter }\end{array}$ & $\begin{array}{l}\text { Urban population exposure to } \\
\text { air pollution by ozone, micro- } \\
\text { grams per cubic meter day }\end{array}$ & $\begin{array}{l}\text { Municipal waste generated per } \\
\text { capita, kg }\end{array}$ \\
\hline & \begin{tabular}{|l|} 
Environ- \\
mentally \\
responsible \\
behaviour \\
\end{tabular} & $\begin{array}{l}\text { Resource productivity, } \\
\text { EUR/kg }\end{array}$ & $\begin{array}{l}\text { The dynamics of energy } \\
\text { productivity in EUR per } \mathrm{kg} \\
\text { of oil equivalent }\end{array}$ & $\begin{array}{l}\text { Recycling rates for packaging } \\
\text { waste, } \%\end{array}$ \\
\hline & $\begin{array}{l}\text { Consump- } \\
\text { tion of } \\
\text { environ- } \\
\text { mental } \\
\text { services }\end{array}$ & $\begin{array}{l}\text { Sufficiency of sites } \\
\text { designated under the } \\
\text { EU Habitats direc- } \\
\text { tive, } \%\end{array}$ & Protected terrestrial areas, $\%$ & $\begin{array}{l}\text { Total area of forests and other } \\
\text { wooded land per capita, ha/capita }\end{array}$ \\
\hline
\end{tabular}

Source: own compilation based on EUROSTAT databases. 
The term of built environment is narrower and refers to the human-made surroundings that has direct impact on life of humans. The housing conditions are the most important issue of built environment having a direct impact on human health and well-being as a source of satisfaction, improves mental well-being, allows people to recover from the stress of everyday life and to perform physical activity (Zheng, 2010), (Liao, 2009). The main housing indicators relevant to quality of life are: housing quality, housing environment and housing expenditures burden indicators. The housing quality is important for human health and other social and physical needs. Housing environment encompass such important issues as safe, convenient and clean living surrounding having direct impact on quality of life. Housing expenditures are also crucial for quality of life as represents the housing affordability. The objective built environment indicators of quality of life presented in this paper are limited to only a subset of indicators reported by EUROSTAT databases.

In Table 1 the natural and built environment indicators relevant to quality of life are presented.

As it can be seen in Table I the main indicators of natural and built environment consists of 6 main groups of indicators addressing the most important issues of built environment and housing and natural environment having impact on quality of life.

\section{QUALITY OF BUILT ENVIRONMENT}

Built environment indicators of quality of life should provide information on quality of housing, quality of housing environment and housing affordability. The justification for inclusion of specific indicators is provided as well.

The quality of housing can be measured by applying two important indicators: the availability of sufficient space in the dwelling and housing comfort.

The main indicator that has been developed to describe space problems is the overcrowding rate, which assesses the proportion of people living in an overcrowded dwelling, as defined by the number of rooms available in the household, the household size, as well as the family members age and situation. This indicator provides information on housing overcrowding, which has long been identified as a major housing problem. Having sufficient space is essential to meet people's basic need for privacy and for making home a pleasant place to be. Too many tenants in a dwelling may also have a negative impact on children's health or school performance.

Housing quality can also be assessed by looking at other housing deficiencies, such as lack of certain basic sanitary facilities in the dwelling (such as a bath or shower or indoor flushing toilet) and problems in the general condition of the dwelling (leaking roof or dwelling being too dark).

The housing deprivation rate is the indicator providing assessment of selected housing deficiencies. The notion of "decent housing" includes other basic aspects of housing conditions, such as the quality of the roofs, floors, doors and window frames, which may also have adverse effects on people's health conditions and comfort. This indicator was selected as the main indicator for assessment of housing comfort.

The other indicator describing housing quality is the share of population considering their dwelling as too dark which is calculated by EUROSTAT and provides important information on living conditions.

The built environment has impact on quality of life not only because of the quality of the dwelling itself, but depending also on the wider residential area. Therefore the other group of built environment indicators refers to the quality of housing environment or housing surroundings.

Recent studies on quality of life indicators revealed that access to green spaces is essential for quality of life, as an unspoiled environment is a source of satisfaction (Balestra, Sultan, 2013), improves mental 
well-being (Brown, Grant, 2007), allows people to recover from the stress of everyday life (Brajša-Žganec, Merkaš, Šverkok, 2010), and to perform physical activity. Cross-sectional studies find that levels of physical activity are higher and obesity is lower in areas with higher levels of greenery (Reto, Garcia-Vega, 2012). However in EUROSTAT data base there are no harmonized indicators to assess the access to green areas in EU member states therefore this issue was not included in the analysis.

The proximity of public services such as schools and hospitals is another important indicator of quality of life related with housing.

The other relevant built environment indicators referring to quality of living environment developed by EUROSTAT are indicators measuring the share of population exposed to the crime, violence or vandalism and to noise and pollution in the area. Living in unsecure area reduces the housing comfort and the price of living area tremendously, therefore this is a significant indicator of quality of life related to housing environment.

The indicator measuring the share of total population exposed to the noise from neighbours or from the street represents an important issue of quality of housing environment as living in a noisy area has negative impact on comfort and human health. Noise pollution is one of the most difficult problems in urban areas and multi-flat houses.

Pollution, grime or exposure to the other environmental problems also have direct impact on human health and living conditions. Large and comfortable dwellings in polluted environment do not provide satisfactory living conditions and this is also reflected in the prices of living area in polluted regions and locations.

The housing expenditures burden indicators represent housing affordability. The main indicator in this group is the housing cost overburden rate. It is measured as the percentage of the population living in households where the total housing costs (net of housing allowances) represent $40 \%$ or more of their equalized disposable income. This indicator is an imperfect proxy of the pressure of housing costs on the household budget: indeed, some middle- and high-income households can decide to spend a large amount ( $40 \%$ or more) of their disposable equalized income on housing, without incurring any form of material deprivation.

Another meaningful indicator developed by EUROSTAT is the share of households able to keep home adequately warm, which represents economic strain linked to dwelling. This indicator is especially important in cold climate countries such as Eastern Europe, including Lithuania as well.

The third indicator in this group - inability to pay utility bills represents the economic strain of households and takes into account high prices for electricity, heat and water supply etc. compared to low income which is especially relevant to new EU member states.

The increase of all built environment indicators shows negative trends and decline in quality of life.

Table 2 displays the dynamics of built environment indicators relevant to quality of life in EU-27.

As it can be seen in Table 2, the trends of housing quality indicators were positive in EU-27 since the economic crisis in 2008. The trends of housing environment indicators were also positive since 2008. As regards indicators of housing environment in 2012 14.1\% of the EU-27 population perceived the area in which they live as being affected by pollution, grime or other environmental problems. Crime and/or vandalism were perceived as a problem by $14.2 \%$ of the EU-27 population in 2011 . At the EU-27 level, the greatest difference of 2.8 percentage points between the total population and the population at-riskof-poverty concerned both noise and crime, violence and vandalism, while the lowest difference (of 1.2 percentage points) concerned pollution. 
The dynamics of quality of built environment in EU-27

\begin{tabular}{|l|c|c|c|c|c|c|}
\hline & 2005 & 2007 & 2008 & 2009 & 2010 & 2012 \\
\hline Housing overcrowding rate, \% & 19.5 & 18.8 & 18.4 & 17.9 & 17.7 & 16.9 \\
\hline Housing deprivation rate, \% & 8.2 & 7.2 & 6.6 & 6.0 & 5.7 & 5.1 \\
\hline $\begin{array}{l}\text { Share of population considering their dwelling as } \\
\text { too dark, \% }\end{array}$ & 8.1 & 8.2 & 7.2 & 7.3 & 6.8 & 6.1 \\
\hline $\begin{array}{l}\text { The share of population exposed to crime, violence } \\
\text { or vandalism in the area, \% }\end{array}$ & 16.0 & 15.9 & 14.7 & 16.0 & 14.4 & 13.7 \\
\hline $\begin{array}{l}\text { The share of population exposed to noise from the } \\
\text { street, \% }\end{array}$ & 24.0 & 23.1 & 21.9 & 22.2 & 20.6 & 18.9 \\
\hline $\begin{array}{l}\text { The share of population exposed to pollution, grime } \\
\text { or other environmental problems }\end{array}$ & 17.6 & 17.1 & 16.2 & 16.5 & 14.8 & 14.1 \\
\hline Housing cost overburden rate, \% & 11.5 & 10.6 & 10.5 & 10.0 & 10.9 & 11.3 \\
\hline $\begin{array}{l}\text { The share of population enable to keep home } \\
\text { adequately warm, \% }\end{array}$ & 12.3 & 10.8 & 10.1 & 9.3 & 9.5 & 10.8 \\
\hline $\begin{array}{l}\text { The share of population enable to pay utility bills, } \\
\%\end{array}$ & 8.3 & 7.3 & 7.9 & 8.9 & 8.9 & 9.7 \\
\hline
\end{tabular}

Source: own compilation based on EUROSTAT databases.

Noise from neighbours or from the street was a problem for $18.9 \%$ of total population in EU in 2012 .

The trends of housing environment indicators development since 2008 were positive in EU-27 and the share of population exposed to pollution, noise and crime has decreased significantly since 2004 in EU-27.

At EU-27 level the percentage of people whose housing costs exceeded $40 \%$ of their equalized disposable income was around $11.5 \%$ for all age groups (people below the age of 18, people in the age of 18-64, over the age of 65). However, this is not the same in all EU Member States. In ten Member States the elderly suffer more than the younger age groups on regards housing cost affordability. The housing costs overburden rate has increased after economic crisis in 2008 however did not reached year 2004 level.

Indicator of inability to keep home adequately warm in EU-27 average reached just $10.8 \%$ in 2012 and has increased since 2004

Inability to pay utility bills in 2012 in EU-27 average was just $9.7 \%$ and has also increased after economic crisis. The highest indicators for inability to pay utility bills are in new EU member states. The best indicators are in Denmark, Iceland, Switzerland and Netherlands. Therefore, though the share of housing costs shoes a large share of households disposable income in old EU member states, they do not cause problems for population to pay such high utility bills because of the average high disposable income comparing with new EU member states.

To conclude it is necessary to stress that the housing quality and housing environment indicators have increased since 2008, indicating that quality of life in term of built environment was growing in EU-27; however the housing expenditures burden indicators had negative trends indicating decrease of quality of life in EU-27 because of economic crisis. 


\section{QUALITY OF NATURAL ENVIRONMENT IN EU}

The natural environment indicators relevant to quality of life consist of environmental quality indicators, consumption of environmental services and environmentally responsible behavior indicators. These 3 groups of indicators represent the most important issues of quality of life in terms of natural environment. The justification for inclusion of the specific indicators is presented further.

The environmental quality indicators encompass a number of environmental media (e.g. soil, water, air). However, due to the lack of relevant data for some of these media and the evidence of sizeable effects of air pollutants on human health, the main attention has been paid to air pollution indicators related to environmental quality. The objective measure of air quality used in this paper takes into account PM10 and ground ozone concentrations only because of harmonized indicators developed by EUROSTAT.

Up to $50 \%$ of the population living in urban areas may have been exposed to levels of ozone that exceed the EU target value. The fraction of the $\mathrm{PM}_{10}$ which are thought to be the most poisonous are less than 2.5 micrometers across and are called $\mathrm{PM}_{2.5}$. Epidemiological studies conducted over the past twenty years have reported significant associations between short-term and long-term exposure to increased ambient PM concentrations and increased morbidity (e.g. cardiovascular and respiratory diseases) and (premature) mortality (Goldberg et. al., 2001). $\mathrm{PM}_{10}$ are readily inhalable and because of their small size are not filtered and reach the upper part of the airways and lungs (Arruti, Fernández-Olmo, Irabien, 2011). Those smaller than 2.5 $\mu \mathrm{m}$ penetrate deep into the bottom of the lung, where they can move to the blood stream, thus allowing many chemicals harmful to human health to reach many internal organs. This can cause a wide range of total illnesses including cancer, brain damage and damage to the fetus. Fine particulate matter $\left(\mathrm{PM}_{2.5}\right)$ in air has been estimated to reduce life expectancy in the EU by more than eight months (Dockery, 2001), (Katsouyanni et. al., 2001). Although it is commonly assumed that there is no threshold below which health effects of PM are unlikely to occur, the recent update of the WHO Air Quality Guidelines for PM proposed that guidelines should be set to minimize the risk of adverse effects of both short-and long-term exposure to PM (WHO, 2004). These values are set at $20 \mu \mathrm{g} / \mathrm{m} 3$ as an annual mean and $50 \mu \mathrm{g} / \mathrm{m} 3$ as a daily mean for $\mathrm{PM}_{10}$, with corresponding values of $10 \mu \mathrm{g} / \mathrm{m} 3$ and $25 \mu \mathrm{g} / \mathrm{m} 3$ for $\mathrm{PM}_{2.5}$

The urban population exposure to ozone indicator shows the population-weighted concentration of ozone to which the urban population is potentially exposed. The principle metric for assessing the effects of ozone on human health is, according to the WHO recommendations, the daily maximum 8-hour mean. Ozone effects should be assessed over a full year. Current evidence is insufficient to derive a level below which ozone has no effect on mortality. However, for practical reason it is recommended to consider an exposure parameter which is the sum of excess of daily maximum 8 -h means over the cut-off of $701 / 4 \mathrm{~g} / \mathrm{m} 3$ $(35 \mathrm{ppb})$ calculated for all days in a year.

The EU's Sixth Environment Action Programme identifies waste prevention and management as one of four top priorities. Its primary objective is to decouple waste generation from economic activity, so that EU growth will no longer lead to more and more rubbish, and there are signs that this is beginning to happen. The EU is aiming for a significant cut in the amount of rubbish generated, through new waste prevention initiatives, better use of resources, and encouraging a shift to more sustainable consumption patterns.

Therefore the main indicator of natural environment quality in this area is municipal waste generated per capita, which indicates the waste accumulation rate and the problem in EU member states.

There are no indicators of natural environment quality in the area of water included in this paper because of limitations of data in EUROSTAT data base.

The increase of these indicators indicates the negative trends and decline in of quality of life. 
The other group of natural environment indicators refers to environmentally responsible behavior. They are associated with resource and energy savings, use of renewable energy sources instead of fossil fuels, waste recycling and proper wastewater management and disposal.

The main indicators of environmentally responsible behavior in EU, selected based on EUROSTAT data, include resource and energy productivity, the share of renewables in final energy consumption, packaging waste recycling rate and sewage sludge production and disposal per capita indicators. These indicators have direct positive impact on quality of life as they are the main drivers of environmental quality indicators. Therefore the increase of these indicators is the desired trend.

Resource productivity is GDP divided by domestic material consumption (DMC). DMC measures the total amount of materials directly used by an economy. It is defined as the annual quantity of raw materials extracted from the domestic territory of the focal economy, plus all physical imports minus all physical exports. If comparisons of resource productivity between countries are made then the GDP in purchasing power standards should be used. Energy productivity is an important indicator assessed by dividing GDP by primary energy consumption. It indicates energy use efficiency in the country.

Between 1990 and 1995, the amount of waste generated in Europe increased by 10\%. Most of what we throw away is either burnt in incinerators, or dumped into landfill sites (67\%). But both these methods create environmental damage. The recycling of waste is the main policy measure to reduce negative impact of waste accumulated, therefore this indicator was included in the systems of quality of life indicators relevant to environmentally responsible behaviour.

The increase of these indicators shows the positive trends and increase in quality of life.

The third group of natural environment indicators consists of indicators referring to consumption of environmental services and amenities selected based on the data provided by EUROSTAT and includes index of sufficiency of sites designated under the EU Habitats directive, the share of protected terrestrial area and the total area of forests and other wooded land per capita.

The increase of these indicators correlates with the increase of use of services provided by environment having direct positive impact on quality of life.

Traditionally, the main function of forests in Europe has been wood production. However, the recreation and tourism functions of forests and woodlands are becoming more important in many European countries. In particular their benefits for economic development, health and well-being and quality of life.

Therefore the main indicators representing consumption of environmental services in EU member states are related with biodiversity and sufficiency of sites designated under the EU Habits directive, protected terrestrial areas, and the area of forests.

Table 3 illustrates the dynamics of natural environment indicators in EU.

Table 3

The dynamics of quality of natural environment in EU-27

\begin{tabular}{|l|c|c|c|c|c|c|}
\hline Indicators & 2005 & 2006 & 2007 & 2008 & 2009 & 2010 \\
\hline \multicolumn{1}{|c|}{1} & 2 & 3 & 4 & 5 & 6 & 7 \\
\hline Urban population exposure to $\mathrm{PM}_{10}$, micrograms per cubic meter & 28 & 30 & 28 & 26 & 26 & 26 \\
\hline $\begin{array}{l}\text { Urban population exposure to air pollution by ozone, micrograms } \\
\text { per cubic meter }\end{array}$ & 3677 & 4478 & 3611 & 3580 & 3648 & 3368 \\
\hline Municipal waste per capita, $\mathrm{kg}$ & 515 & 521 & 522 & 519 & 509 & 505 \\
\hline Resource productivity in EU, EUR/kg & 1.4 & 1.42 & 1.43 & 1.46 & 1.57 & 1.65 \\
\hline Energy productivity in EUR per kg of oil equivalent & 6.1 & 6.3 & 6.5 & 6.6 & 6.7 & 6.6 \\
\hline
\end{tabular}




\begin{tabular}{|l|c|c|c|c|c|c|}
\hline \multicolumn{1}{|c|}{1} & 2 & 3 & 4 & 5 & 6 & 7 \\
\hline Recycling rates for packaging waste, \% & 54.6 & 56.9 & 59.2 & 60.5 & 62.5 & 63.3 \\
\hline Sufficiency of sites designated under the EU Habitats directive, \% & 80 & 83 & 84 & 84 & - & 89 \\
\hline Protected terrestrial area, \% & 14 & 14 & 14 & 14 & 14 & 14 \\
\hline Total area of forests and other wooded land per capita & 0.36 & - & - & - & 0.35 & 0.35 \\
\hline
\end{tabular}

Source: own compilation based on EUROSTAT databases

The information provided in Table 3 shows the dynamics of environmental quality indicators in EU-27 average with positive trends for all analyzed indicators. However, these positive trends can be noticed just since 2008 economic crisis. Therefore, the economic crisis has impact on economic development decline, atmospheric pollution and waste reduction. The dynamics of indicators representing environmentally responsible behavior also has positive trends since economic crisis of 2008. The resource productivity, energy productivity and recycling rate of waste have increased since economic crisis, therefore environmentally responsible behavior indicators had positive impact on environmental quality indicators during the same period 2008-2011. The trends of consumption of environmental services during the same period were positive for Sufficiency of sites designated under the EU Habitats directive indicator in EU-27 however the share of protected terrestrial area and the share of forests per capita was stable during the same period.

\section{CONCLUSION}

Measuring of built and natural environment indicators and their effects on people's well-being is a complex task, because there are very few comparable indicators.

The developed indicators framework can be easy applied for monitoring built and natural environment dimensions in the assessment of quality of life in EU, as it includes the main environmental indicators developed and openly published by EUROSTAT.

The developed indicators framework allows comparing EU member states in their achievements of increasing quality of life in terms of environmental indicators and is a good tool for monitoring success of implemented environmental policies.

The proposed system of built environment indicators relevant to quality of life includes: housing quality, housing environment and housing cost burden indicators.

The proposed system of natural environment indicators relevant to quality of life includes: environmental quality indicators, environmentally responsible behaviour indicators and indicators of consumption of environmental services.

The analysis of trends of built environment indicators in EU-27 indicated that though the housing quality and housing environment indicators have increased since 2008, indicating that quality of life in term of built environment was growing in EU-27, the housing expenditures burden indicators had negative trends, which indicates a decrease of quality of life in EU-27 because of economic crisis.

Analysis of the dynamics of natural environmental quality indicators in EU-27 average indicated the positive trends for all analysed indicators; however, these positive trends can be noticed just since 2008 economic crisis. Therefore economic crisis had impact on economic development decline and atmospheric pollution and waste reduction.

The dynamics of indicators representing the environmentally responsible behaviour also had positive trends during the same period and indicators of consumption of environmental services were stable in EU-27. 
The overall quality of life index was not assessed in this paper because the focus of the paper is natural and built environment indicators of quality of life. The author of paper analized this important issue of assessment of quality of life during the project funded by the European Social Fund under the Global Grant measure.

The results of overall quality of life assessment in EU will be addressed in following publications of the group of authors dealing with specific dimensions of quality of life index.

\section{ACKNOWLEDGMENT}

This research is funded by the European Social Fund under the Global Grant measure (No. VP1-3.1-ŠMM07-K-03-032).

\section{REFERENCES}

A. Arruti, I. Fernández-Olmo, and A. Irabien, (2011), Impact of the global economic crisis on metal levels in particulate matter (PM) at an urban area in the Cantabria Region (Northern Spain), Journal of Environmental Monitoring, vol. 159 (1), pp. 1129-1135, Ma.

A. Brajša-Žganec, M. Merkaš, and I. Šverko, (2010), Quality of life and leisure activities: How do leisure activities contribute to subjective well-being?, Social Indicators Research, vol. 102 (1), pp. 80-97, September.

B. Mace, P. Bell and R. Loomis, (1999), Aesthetic, affective, and cognitive effects of noise on natural landscape assessment, Social and Natural Resources, vol. 12(3), pp. 225-242.

C. Balestra and D. Dottori, (2012), Ageing society, health and the environment, Journal of Population Economics, vol. 25(3), pp. 1045-1076, July.

C. Balestra and J. Sultan, (2013), Home sweet home: The determinants of residential satisfaction and its relation with wellbeing, OECD Statistics Directorate Working Papers, OECD, Paris.

C. Brown and M. Grant, (2007), Natural medicine for planners, Town and Country Planning, vol. 7(2):, pp. 67-69, 2007.

D. Streimikiene, (2014), Comparative Assessment of Environmental Indicators of Quality of Life in Romania and Lithuania, Economics \& Sociology, Vol. 7, No 1, pp. 11-21. DOI: 10.14254/2071-789X.2014/7-1/2

D. W. Dockery, (2001), Epidemiologic evidence of cardiovascular effects of particulate air pollution, Environmental health perspectives, vol. 109, pp. 483-486, August.

E. Diener and S. Eunkook, (1997), Measuring quality of life: economic, social and subjective indicators, Social Indicators Research, vol. 40(1-2), pp. 189-216.

E. Rybakovas, (2011), Determinants of strategy for improving the quality of life in local place, Social science, vol. 4 (74), pp. 50-62.

E. Rybakovas, (2012), Quality of Life Peculiarities in Lithuanian regions, Economics and Management, vol. 17 (1), pp. 209-215.

E. Tvaronaviciene, (2011), The Quality of Life of the Lithuanian population, Intellectual Economics, vol. 5(4), pp. 644648.

F. Reto and J. Garcia-Vega, (2012), Quality of life in Mexico: a formative measurement approach, Applied Research in Quality of Life, vol. 7 (3), pp. 220-230, September.

J. F. Helliwell. and C. P. Barrington-Leigh, (2010), Measuring and Understanding Subjective Well-being, Canadian Journal of Economics, vol. 43(3), pp. 729-753, August.

J. Pretty, J. Peacock, M. Sellens, M. Griffin, (2005), The mental and physical health outcomes of green exercise, International Journal of Environmental Health Research, vol. 15(5), pp. 319-337. 
J. Thogersen, (2006), Norms for environmentally responsible behaviour: an extended taxonomy, Journal of Environmental Psychology, vol. 26(4), pp. 247-261, December.

K. D. Van Liere and R. E. Dunlap, (1980), The social bases of environmental concern: A review of hypotheses, explanations, and empirical evidence, Public Opinion Quarterly, vol. 44(2), pp. 181-197.

K. Katsouyanni et al., (2001), Confounding and effect modification in the short-term effects of ambient particles on total mortality: Results from 29 European cities within the APHEA2 project, Epidemiology, vol. 12(5), pp. 521531,2001

M. A. Mohit, (2013), Quality of life in natural and built environment -an introductory analysis, Procedia-Social and Behavioural Sciences, vol. 101, pp. 33-43, November.

M. E. Kahn and J. G. Matsusaka, (1997), Demand for environmental goods: Evidence from voting patterns on California Initiatives, Journal of Law \& Economics, vol. 40(1), pp. 137-173, April.

M. E. Kahn, (2002), Demographic change and the demand for environmental regulation, Journal of Policy Analysis and Management, vol. 21(1), pp. 45-62.

M. R. Holman and T. G. Coan, (2008), Voting Green, Social Science Quarterly, vol. 89, pp. 1121-1135, December.

M. S. Goldberg et al., (2001), Identification of persons with cardio-respiratory conditions who are at risk of dying from the acute effects of ambient air particles, American Journal of Epidemiology, vol. 109, pp. 487-494, August.

N. Ahmad and N. Yamano, (2011), Carbon Dioxide Emissions Embodied in Goods and Services: Domestic Consumption versus Production, OECD Statistics Directorate Working Papers, OECD, Paris.

O. G. Rakauskiene, V. Servetkiene, (2011), The Quality of Life of Lithuanian population: 20 years in market economy, Vilnius, Lithuania: MRU.

P. Dolan, T. Peasgood, and M. White, (2008), Do we really know what makes us happy? A review of the economic literature on the factors associated with subjective well-being, Journal of Economic Psychology, vol. 29, pp. 94-122, February.

P. S. Liao, (2009), Parallels Between Objective Indicators and Subjective Perceptions of Quality of Life: A Study of Metropolitan and County Areas in Taiwan, Social Indicators Research, vol. 91(1), pp. 89- 99, March.

R. Boarini, M. Comola, F. De Keulenauer, R. Manchin and C. Smith, (2010), The Determinants of Well-being in OECD Countries, OECD Statistics Directorate Working Paper, Paris.

R. Osbaldiston and K. M. Sheldon, (2003), Promoting internalized motivation for environmentally responsible behavior: A prospective study of environmental goals, Journal of Environmental Psychology, vol. 23(4), pp. 349-357, December.

V. Albouy, P. Godefroy and S. Lollivier, (2010), Une mesure de la qualité de vie, in INSEE, France, Paris, Portrait Social, pp. 99-114.

Y. Zheng, (2010), Association Analysis on Pro-environmental Behaviors and Environmental Consciousness in Main Cities of East Asia, Behaviormetrika, vol. 37(1), pp. 55-69. 